\title{
EXTRACTED PEARL GRASS EFFECT ON BROILER CARCASS KEPT ON Escherichia coli - SPRAYED LITTER
}

\author{
Nurhayati $^{1}$, M. Latief $^{2}$ and A. Insulistyowati ${ }^{1}$ \\ ${ }^{1}$ Faculty of Animal Science, University of Jambi, \\ Kampus Pinang Masak KM 15 Mendalo Jambi 36361 - Indonesia \\ ${ }^{2}$ Faculty of Agriculture, University of Jambi, \\ Kampus Pinang Masak KM 15 Mendalo Jambi 36361- Indonesia \\ Corresponding E-mail: nuragus2003@yahoo.de
}

Received March 02, 2010; Accepted May 07, 2010

\begin{abstract}
An experiment was conducted to determine the effect of hexane and acetic ethyl extracted pearl grass as feed additive in the ration on carcass of broiler chickens where the litter was sprayed by Escherichia coli. The experiment was assigned to Completely Randomized Design with 5 treatments and 4 replications. The treatments were level of pearl grass extract added into the ration; 0 (R0, control), $0.8(\mathrm{R} 1), 1.6(\mathrm{R} 2), 2.4(\mathrm{R} 3)$ dan $3.2(\mathrm{R} 4)$ gram per kilogram ration. After 3 weeks of age, litters were sprayed by Escherichia coli as much as $10^{6} \mathrm{CFU} / 100 \mathrm{ml}$ liquid agar. Then, chickens were kept until 6 weeks of age. Result showed that there was no significant different among treatments groups on chicken carcass and there was no any adverse effect on liver and intestines. It is concluded that extracted pearl grass could be utilized as natural feed additive source to produce carcass of broiler chicken where their litter was sprayed by $E$. coli bacteria.
\end{abstract}

Keywords: broiler carcass, Escherichia coli, Hedyotis corymbosa, pearl grass

\section{INTRODUCTION}

Utilization synthetical antibiotics, medicine or feed additive to prevent and treat animal diseases cause microbes resistance in digestive tract (Van den Bogaard et al., 2001), produce metabilte products of the antibiotics, medicine or feed additive in form of residue in animal products such as milk, meat, egg and animal tissues (Jetacar, 1999) those might be transferred to human who consumed it. Ladefoged (1996) reported that antibiotic residues in digestive tract could prevent microflora growth and digestion disorder. Mumtaz et al. (2000) reported that drug residue was detected in poultry meat in few days after drug ingestion and contaminated meat could disturb human health. Naeem et al. (2006) detected more Quinolones residue in liver and kidney than in chicken meat and egg. The residue might be accumulated into human body who consumed the animal products contained antibiotic residue and could cause allergy, resistance (Sundlof and Cooper, 1996), hypersensitive to stimulant, carcinogenic, mutagenic and toxicity (Voogd, 1981).

These circumstances and people realization to have healthy life and people need to back to nature persuade people to reduce and stop using synthetic antibiotics and drugs in their life and also in animal husbandry. They use alternative herbs such as pearl grass (Hedyotis corymbosa or Oldenlandia corymbosa $\mathrm{L}$ ) that is classified into genus Hedyotis, family Rubiaceae.

Pearl grass until the present time is usually used by community to treat digestion disorder, cancer, caecum sore, microbial infection (bacteria, protozoa and fungi) and (Dalimartha, 2002). Nurhayati et. al (2006) reported that pearl grass could inhibit bacterial growth including E.coli but it could not inhibit Candida albicans growth. The highest activity of extracted pearl grass was found in acid and base etyl acetate fraction and followed by methanol and $n$-hexane fraction. Nurhayati and Latief (2009) found that keton group (tersier butil isopropil keton) in extracted pearl grass could inhibit E.coli growth. Pearl grass contained $90.28 \%$ dry matter, $14.93 \%$ crude protein, and $556.81 \mathrm{kcal} / \mathrm{kg}$ gross energi. However, due to the lack of publication of pearl grass effect on animal especially on poultry causes this medicinal weed are not used either as antimicrobes or feed additive in livestock including poultry. Based on 
this reason the current study was conducted to determine the effect of hexane and acetic ethyl extracted pearl grass as feed additive in the ration on carcass of broiler chickens where the litter was sprayed by Escherichia coli.

\section{MATERIALS AND METHODS}

\section{Pearl Grass Extract, Birds, Diets and Housing}

Pearl grass used in this study was collected from Jambi Regency. Then it was sorted, cleaned, chopped and extracted by maseration using organic solvent namely acetic etyl for $2 \times 3 \times 3$ days until all active compounds were dissolved. Thereafter, all solvent were evaporated by vacuum rotary evaporator to get pearl grass extract. The extract was dried under room temperature before it was added into the basal diet based on the treatment level.

A hundred two days-old male broiler chicks with $47.69 \pm 3.79$ gram of average weight were purchased from a commercial hatchery in Palembang were used in this study. Chicks were randomly divided equally to 5 experimental treatments. The design of experiment was assigned into Completely Randomized Design. The treatments were :

R0 : Basal diet +0 g pearl grass extract

$\mathrm{R} 1$ : Basal diet $+0.8 \mathrm{~g}$ pearl grass extract per $\mathrm{kg}$ diet

R2 : Basal diet $+1.6 \mathrm{~g}$ pearl grass extract per $\mathrm{kg}$ diet

$\mathrm{R} 3$ : Basal diet $+2.4 \mathrm{~g}$ pearl grass extract per $\mathrm{kg}$ diet

R4 : Basal diet +3.2 g pearl grass extract per $\mathrm{kg}$ diet

Each treatment had 4 replicates of 5 chicks.

Chicks of each replicate were housed in colony floor pens with deep litter and were fed the experimental diet for a period of 42 days.

Basal diet was differed into starter diet (until 3 weeks of age) and finisher diet (after 3 weeks of age) as shown in Table 1. Chemical composition of treatment diets are shown in Table 2 and Table 3. The diet was offered into the chicken ad libitum.

At 4 days of age, chicks were vaccinated by ND vaccine strain Lasota B1 through eye drops. Other vaccines were not injected. After 3 weeks of age, litter was sprayed with Escherichia coli as much as $10^{6} \mathrm{CFU} / 100 \mathrm{ml}$ of liquid agar. Then, chickens were kept until 6 weeks of age. At 42 days of age, 2 chickens with the nearest average live body weight was randomly selected from each treatment and were deprived of feed for $8 \mathrm{~h}$ prior to slaughtering. The chickens were weighed and were exsanguinated. Chickens were bled, scalded and feathered. Feet were removed manually by severing the intra tarsal joint. Carcass was manually eviscerated and abdominal fat, liver, gizzard, heart and giblets were removed and were weighed to calculate organ weight and carcass weight.

\section{Statistical Analysis}

Parameters determined in this study were feed consumption, live weight, carcass percentage, liver percentage, gizzard percentage and intestinal percentage. The effect of diet on chicken carcass characteristics and organ weights were analyzed by one-way ANOVA using General Linear Model procedure of SAS (version 6.04) (SAS Institute, 1994). Significant differences among treatment means were separated using Duncan's Multiple Range Test. The statistical model used for analyzing data obtained was :

where :

$$
Y_{i j}=M+T_{i}+E_{i j}
$$

$\mathrm{Y}_{\mathrm{ij}}=$ the individual observation

$\mathrm{M}=$ the overall mean

$\mathrm{T}_{\mathrm{i}}=$ The effect of pearl grass extract addition

$\mathrm{E}_{\mathrm{ij}}=$ the experimental error

Table 1. Basal Diet Composition (\%)

\begin{tabular}{lcc}
\hline \multirow{2}{*}{ Ingredients } & Starter Diet & Finisher Diet \\
\cline { 2 - 3 } & $(0-3$ week $)$ & $(3-6$ week $)$ \\
\hline Yellow corn & 40.3 & 45.3 \\
Polish & 10 & 15 \\
Soybean meal & 30 & 25 \\
Fish meal & 15 & 10 \\
Dicalsium phosphat & 1.2 & 1.2 \\
Vegetable oil & 2 & 2 \\
Premix & 1 & 1 \\
Methionin & 0.5 & 0.5 \\
\hline Total & 100 & 100 \\
\hline Dry matter $(\%)$ & 85.64 & 86.06 \\
Crude protein $(\%)$ & 24.12 & 23.26 \\
Crude fibre (\%) & 3.76 & 3.7 \\
Ether extract $(\%)$ & 7.15 & 5.71 \\
Ash (\%) & 6.04 & 5.22 \\
NFE (\%) & 44.57 & 48.16 \\
GE(kcal/kg) & 4281.74 & 4269.89 \\
ME (kcal/kg) & 3104.26 & 3095.67 \\
\hline
\end{tabular}


Table 2. Chemical Composition of Starter Diets ( $0-3$ weeks)

\begin{tabular}{lrrrrr}
\hline \multirow{2}{*}{\multicolumn{1}{c}{ Parameters }} & \multicolumn{5}{c}{ Treatment } \\
\cline { 2 - 6 } & \multicolumn{1}{c}{ R0 } & \multicolumn{1}{c}{ R1 } & \multicolumn{1}{c}{ R3 } & \multicolumn{1}{c}{ R4 } \\
\hline Dry matter (\%) & 85.64 & 85.71 & 85.78 & 85.86 & 85.93 \\
Crude protein (\%) & 24.12 & 24.13 & 24.14 & 24.15 & 24.17 \\
Crude fibre (\%) & 3.76 & 3.79 & 3.81 & 3.84 & 3.86 \\
Ether extract (\%) & 7.15 & 7.15 & 7.15 & 7.15 & 7.16 \\
Ash (\%) & 6.04 & 6.05 & 6.06 & 6.07 & 6.08 \\
NFE (\%) & 44.57 & 44.6 & 44.62 & 44.64 & 44.67 \\
\hline GE (kcal/kg) & 4281.74 & 4282.18 & 4282.63 & 4283.08 & 4283.52 \\
EM (kcal/kg) & 3104.26 & 3104.58 & 3104.91 & 3105.23 & 3105.55 \\
\hline
\end{tabular}

Table 3. Chemical Composition of Finisher Diets ( $3-6$ weeks)

\begin{tabular}{lrrrrr}
\hline \multirow{2}{*}{\multicolumn{1}{c}{ Parameters }} & \multicolumn{5}{c}{ Treatment } \\
\cline { 2 - 6 } & \multicolumn{1}{c}{ R0 } & \multicolumn{1}{c}{ R1 } & \multicolumn{1}{c}{ R2 } & \multicolumn{1}{c}{ R3 } & \multicolumn{1}{c}{ R4 } \\
\hline Dry matter (\%) & 86.06 & 86.13 & 86.2 & 86.27 & 86.35 \\
Crude protein (\%) & 23.26 & 23.27 & 23.28 & 23.3 & 23.31 \\
Crude fibre (\%) & 3.7 & 3.72 & 3.75 & 3.77 & 3.8 \\
Ether extract (\%) & 5.71 & 5.71 & 5.72 & 5.72 & 5.72 \\
Ash (\%) & 5.22 & 5.23 & 5.24 & 5.25 & 5.26 \\
NFE (\%) & 48.16 & 48.19 & 48.21 & 48.23 & 48.26 \\
\hline GE (kcal/kg) & 4269.89 & 4270.33 & 4270.78 & 4271.22 & 4271.67 \\
EM (kcal/kg) & 3095.67 & 3095.99 & 3096.31 & 3096.64 & 3096.96 \\
\hline
\end{tabular}

\section{RESULTS AND DISCUSSION}

Effect of dietary treatment diets on feed consumption, carcass characteristics and organ weight of broiler chicken is shown in Table 4 .

\section{Feed Consumption}

Analysis of variance showed that there was no difference $(\mathrm{P}>0.05)$ effect of addition pearl grass extract into the ration of broiler chickens where their litter was sprayed with $E$. coli bacteria was found in feed consumption during the overall period. It means that pearl grass extract did not influence diet palatability and chicken appetite. It is due to that the experimental diet among treatment groups had similar quality (Table 2 and 3). Besides it might be due to the flavonoid, steroid and aromatic compound in pearl grass did not disturb chicken appetite. The similar effect also reported by other authors who offered herbs or medicinal plants as feed additive on broiler' feed consumption. Nurhayati et al. (2005) reported that chickens were offered $0,2.5,5.0,7.5$ and $10 \%$ of pace meal had similar $(\mathrm{P}>0.05)$ feed consumption and pace meal did not significantly $(\mathrm{P}>0.05)$ increase feed consumption. Lohakare $e t$ al. (2006) reported that lacquer is usually used as traditional medicine by Japanese, Chinese and Korean. There was no different effect among 0, 1 , 2 and $4 \%$ of lacquer meal on increasing broiler feed consumption. The similar effect of pearl grass extract on feed consumption even though house litter was sprayed by $10^{6} \mathrm{CFU}$ E. coli bacteria per $100 \mathrm{ml}$ liquid agar showed that the active compounds in pearl grass had synergetic effect on controlling and limiting bacteria growth. Nurhayati et al. (2006); Nurhayati and Latief (2009) found that pearl grass could inhibit E.coli growth in vitro. Inhibited microbes growth in the gut would cause the nutrient could be utilised by animal itself and he would not need more nutrient for maintenance, growth and production.

Table 4 showed that feed consumption of broiler chicken during the experiment was 556.41 $\mathrm{g} / \mathrm{bird} /$ week or $79 \mathrm{~g} / \mathrm{bird} /$ day in average. This result was not significantly different by previous report by Nurhayati et al. (2009) who offered ration containing different medicinal weed namely bandotan (Ageratum conyzoides L), patikan kebo (Euphorbia hirta L) and sidaguri (Sida cordifolia) to the broiler chicken. Daily feed consumption of chicken fed $5 \%$ of bandotan, patikan kebo and sidaguri in the ration were $76.48,78.40$ and $74.29 \%$, respectively. 
Table 4. Effect of Dietary Treatment Diets on Carcass Characteristics

\begin{tabular}{lrrrrrr}
\hline \multirow{2}{*}{ Parameters } & \multicolumn{7}{c}{ Treatment } & \multicolumn{1}{c}{ Mean \pm SD } \\
\cline { 2 - 6 } & \multicolumn{1}{c}{ R0 } & \multicolumn{1}{c}{ R1 } & \multicolumn{1}{c}{ R2 } & \multicolumn{1}{c}{ R3 } & \multicolumn{1}{c}{ R4 } & \\
\hline FC $(\mathrm{g} / \mathrm{h} / \mathrm{wk})$ & 579.69 & 568.98 & 555.53 & 548.31 & 529.54 & $556.41 \pm 19.29$ \\
LW $(\mathrm{g} / \mathrm{b})$ & 1217.50 & 1231.50 & 1243.88 & 1265.38 & 1276.88 & $1247.03 \pm 24.24$ \\
Carcass (\%) & 65.5 & 66.4 & 68.31 & 67.6 & 68.61 & $67.28 \pm 1.31$ \\
Liver (\%) & 2.84 & 2.88 & 2.72 & 2.67 & 2.96 & $2.81 \pm 0.12$ \\
Gizzard (\%) & 0.83 & 0.81 & 0.72 & 0.78 & 0.74 & $0.78 \pm 0.08$ \\
Intestinal (\%) & 3.26 & 3.18 & 3.12 & 3.08 & 3.3 & $3.19 \pm 0.09$ \\
\hline
\end{tabular}

$\mathrm{FC}=$ feed consumption $(\mathrm{gram} / \mathrm{head} /$ week $), \mathrm{LW}=$ live weight $(\mathrm{gram} / \mathrm{bird})$.

No differ significantly $(\mathrm{P}>0.05)$

\section{Liveweight and Carcass}

Analysis of variance showed that hexane and acetic ethyl extracted pearl grass addition into the ration up to $3.2 \mathrm{~g} / \mathrm{kg}$ did not significantly $(\mathrm{P}>0.05)$ influence live weight and carcass percentage. This result was parallel to feed consumption and daily weight gain those were also not significantly different among the treatment groups. No difference on these parameters even though the litter was sprayed with $E$. coli bacteria might be due to that the nutrients and active compounds in the pearl grass have banded in nutrient digestive process and have synergetic effect to increase birds resistance on E-coli bacteria. As reported by Nurhayati et al. (2006); Nurhayati and Latief (2009) that pearl grass contained active ingredients those could inhibit bacterial growth including E.coli. Buchanan et al. (2009) reported that medicinal plants contained phytogenic compounds, essential oils and organic acid those could reduce pathogenic bacteria in the chicken. It was similar results were reported by previous authors (Dickens et al., 2000; Dorman et al., 2000; Abd El-Latif, 2002; Al-Harthi, 2002; Hassan, et al., 2004; Buchanan et al., 2008; Javed et al., 2009; Onibi et al., 2009) who fed briler chicken with the diet consists of herbs or medicinal plants. They reported that there was a positive effect of feeding herbal feed additive on broiler performance due to that herbal supplementation or medicinal plant supplementation could improve nutrient digestive process, thus, in could chicken body weight gain and at the end increase slaughter weight of chicken. Hernandez et al. (2004) stated that essential oils in the medicinal plants might increase broiler chicken digestion. Uunganbayar et al. (2006) concluded that green tea mixed into the broiler chicken had no adverse effect on broiler performance. Onibi et al (2009) found that quality and aroma of meat increased by supplemented garlic into the ration. The best level was $5 \mathrm{~g} / \mathrm{kg}$ diet resulted $2.1 \mathrm{~kg}$ body weights at 56 days of age. Javed et al. (2009) reported that feeding some medicinal plants extract as much as $10 \mathrm{ml} / \mathrm{L}$ drinking water produced $1.4 \mathrm{~kg}$ body weight at 35 days old and carcass was $62 \%$ in average.

\section{Organs Weight}

Analysis of variance showed that hexane and acetic ethyl extracted pearl grass addition into the ration was not significantly $(\mathrm{P}>0.05)$ effect on organs (liver, gizzard, and intestine) weight. There was no adverse effect also on colour of liver. There was no blood spot on the intestine, no thickening on gizzard and intestine wall. These results mean that pearl grass extract had not toxic effect, thus, it would not cause gizzard, liver and intestine work harder than usual in digestion and absorbance of nutrients. The current result was similar to previous study on mice that ingested single dose pearl grass extract orally. There was no toxicity on mice those received. The current study also showed that $E$. coli could not grow and develop in the digestive tract. It is due to that $E$. coli might be inhibited by active compounds in the pearl grass extract those were fed by chickens. Nurhayati and Latief (2009) detected 3 active compounds in the pearl grass extract namely 4metil-2-en-heksanol, tersier butil isopropil keton, and stigmasta-5,22-dien-3-ol. The highest E. coli antibacterial activity in vitro was detected on tersier butil isopropil keton. Further, Buchanan et al. (2009) reported that essential oils, organic acid and phytogenic compounds in plants reduced number of bacteria in the animal body significantly. 


\section{CONCLUSION}

It is concluded that extracted pearl grass could be utilized as natural feed additive source to produce carcass of broiler chicken where their litter was sprayed by $E$. coli bacteria.

\section{ACKNOWLEDGMENT}

Authors would like to express their gratitude to DP2M Directorate General Higher Education for grant of Fundamental research financial 2009. Head of Research Centre University of Jambi and Dean of Faculty of Animal Science University of Jambi for permission and support, the assistance of staffs and students of Dept. Animal Nutrition and Feed Science, Faculty of Animal Science, University of Jambi for the care and management of birds is acknowledged.

\section{REFERENCES}

Abd El-Latif, S.A., F. A. Ahmed and A.M. ElKaiaty. 2002. Effect of feeding dietary Thyme, Black Cumin, Dianthus and Fennel on productive and some metabolic responses of growing Japanese quail. Egypt. Poult. Sci., 22(1):109-125.

Al-Harthi, M. A. 2002. Performance and carcass characteristics of broiler chicks as affected by different dietary types and levels of herbs and spices as non classical growth promoters. Egypt. Poult. Sci., 22:325-343.

Buchanan, N.P., J. M. Hott, S. E. Cutlip, A. L. Rack, A. Asamer, and J. S. Moritz. 2008. The Effects of a Natural Antibiotic Alternative and A Natural Growth Promoter Feed Additive on Broiler Performance and Carcass Quality. J. Appl. Poult. Res. 17:202 - 210.

Dalimartha, S. 2002. Tumbuhan obat untuk mengatasi keputihan. Cetakan II. Trubus Agriwidya, Jakarta.

Dickens, J.A. ; M. E. Berrang and N.A. Cox. 2000. Efficacy of an herbal extract on microbiological quality of broiler carcass during asimulated chill. Poult. Sci., 79:12001203.

Djauhari, E. dan Hernani. 2004. Gulma berkhasiat obat. Seri Agrisehat. Penebar Swadaya, Jakarta.

Dorman, H.J.D., P. Surai and S.G. Deans. 2000. In vitro anti-oxidant activity of a number of plant essential oils and phytoconstituents. J. Essent. Oil Res., 12:241-248.

Hassan, I. I., A. A. Askar and G. A. El-Shourbagy. 2004. Influence of some medicinal plants on performance ; physiological and meat quality traits of broiler chicks. Egypt. Poult. Sci., 24:247-266.

Hernandez, F., J. Madrid, V. Garcia, J. Orengo, and M. D. Megias. 2004. Influence of two plant extracts on broilers performance, digestibility, and digestive organ size. Poult. Sci. 83:169-174.

Javed, M., F-R. Durrani, A. Hafeez, R. U. Khan dand I. Ahmad. 2009. Effect of aqueous extract of plant mixture on carcass quality of broiler chicks. ARPN Journal of Agricultural and Biological Science 4 (1):37-40.

Jetacar (Joint Expert Advisory Committee On Antibiotik Resistance). 1999. The Use of Antibiotiks in Food-Producing Animals: Antibiotik-Resistant Bacteria in Animals and Humans. Commonwealth Department Of Health And Aged Care Commonwealth Department Of Agriculture, Fisheries And Forestry, Australia.

Ladefoged, O. 1996. Drug residues in food of animal origin and related human hazards. In: Proc. Int. Workshop on Rational Applications of Vet. Pharmaceuticals and Biologicals. Balochistan Livestock Dev. Project, L \& DD, Govt. of Balochistan, Quetta. March 1-3, 1996. Pp. 246-253.

Lohakare, J.D., J. Zheng, J.H. Yun and B.J. Chae, 2006. Effect of Lacquer (Rhus verniciflua) Supplementation on Growth Performance, Nutrient Digestibility, Carcass Traits and Serum Profile of Broiler Chickens. AsianAust. J. Anim. Sci. 19 (3) : 418 - 424.

Mumtaz, A., J. A. Awan and M. Athar, 2000. Rational use of drugs in broiler meat production. Int. J. Agri. Biol. 2(3) : $269-$ 272.

Naeem, M., K. Khan and S. Rafiq, 2006. Determination of residues of quinolones in poultry products by High Pressure Liquid Chromatography. J. Applied Sci. 6 (2) : 373 379.

Nurhayati, M. Latief and H. Handoko, 2006. Uji Antimikroba Rumput Mutiara (Hedyotis corymbosa) terhadap Bakteri dan Jamur Penyebab Penyakit pada Ternak Unggas. Journal Biosfera 23(3):137-143.

Nurhayati and M. Latief. 2009. Isolasi Senyawa dan Uji Antibakteri Ekstrak Etil Asetat 
Rumput Mutiara (Hedyotis corymbosa L (Lamk)) Terhadap Bakteri Escherichia. Jurnal Bahan Alam Indonesia 6 (6) : 243 246.

Nurhayati, Nelwida and Marsadayanti, 2005. Pengaruh Penggunaan Tepung Buah Mengkudu dalam Ransum terhadap Bobot Karkas Ayam pedaging. J. Pengembangan Peternakan Tropis 30 (2):96-101.

Nurhayati, Nelwida and H. Handoko. 2009. Comparison of medicinal weeds in the ration on broiler chickens performance. Journal of Animal Production (Jurnal Produksi Ternak) 11(2):103-108.

Onibi, G.E., O. E. Adebisi, A. N. Fajemisin and A.V. Adetunji. 2009. Response of broiler chickens in terms of performance and meat quality to garlic (Allium sativum) supplementation. African Journal of Agricultural Research Vol. 4 (5):511-517.

SAS Institute. 1994. SAS/STAT User's Guide:
Statistics Version 6.04. SAS Institute Inc., Cary, NC.

Sundlof, S.F. and J. Cooper. 1996. Human health risks associated with drug residues in animalderived foods. In: Moats, W.A. and Medina, M.B. (eds). 1996. Veterinary Drug Residues: Food Safety. Symposium Series American Chemical Society. 636:5-17.

Uunganbayar, D., I.S. Shin and C.J. Yang. 2006. Comparative Performance of Hens Fed Diets Containing Korean, Japanese and Chinese Green Tea. Asian-Aust. J. Anim. Sci. 19(8):1190-1196.

Van den Bogaard, A.E., N. London, C. Driesen, and E.E. Stobberingh. 2001. Antibiotic resistance of faecal Eschericia coli in poultry, poultry farmers and poultry slaughterers. J. Antimicrobial Chemotherapy 47:763- 771.

Voogd, C.E. 1981. On the mutagenicity of nitroimidazoles. Mutat. Res. 86(3):243-277. 